Web page: jurnal.ugm.ac.id/v3/jaci

\title{
Revascularization of Acute Limb Ischemia
}

\author{
Budi Yuli Setianto*, Ahmad Faisal
}

Department of Cardiology and Vascular Medicine, Faculty of Medicine, Public Health and Nursing, Universitas Gajah MadaDr. Sardjito Hospital Yogyakarta, Indonesia

\section{ARTICLE INFO}

${ }^{*}$ Corresponding author email:

budyuls@ugm.ac.id

address:

Jalan Farmako Sekip Utara,

Yogyakarta 55281,

Indonesia

Keywords:

acute limb ischemia; medical emergency; reperfusion

Manuscript submitted: July 4, 2020

Revised and accepted: August 5, 2020

\begin{abstract}
Acute limb ischemia (ALI) is a medical emergency which can lead to loss of limb and even death. The outcomes are depending on the immediacy and completeness of revascularization or reperfusion. Generally, the considered a golden period in the management ALI is 6 hours. Unfortunately, the handling of patients with ALI is often too late. Currently there are several methods of revascularization such as thrombolysis (catheter directed thrombolysis), percutaneous and open surgical mechanical thrombectomy. The selection method where is the best revascularization remains controversial. Some research suggests that outcomes did not differ between thrombolysis and surgical therapy.
\end{abstract}

\section{INTISARI}

Iskemia tungkai akut(ALI) merupakan suatu kegawat - daruratan medis yang dapat menyebabkan hilangnya ekstremitas bawah bahkan sampai kematian. Luaran pasien tergantung pada kecepatan dan sempurnanya revaskularisasi atau reperfusi. Umumnya yang dianggap periode emas dalam penatalaksanan ALI adalah 6 jam. Sayangnya penanganan pasien ALI masih sering terlambat. Saat ini terdapat beberapa metode revaskularisasise pertitrombolisis (catheter directed thrombolysis), percutaneus mechanical thrombektomi dan bedah terbuka. Pemilihan

Metode revaskularisasi mana yang paling baik masih menjadi kontroversi. Beberapa penelitian menunjukkan luaran yang tidak berbeda antara terapi trombolisis dengan bedah.

\section{Introduction}

Acute limb ischemia (ALI) is a condition where there is a sudden blockage of blood flow in the lower extremities that can threaten the viability of the extremities and occur within a period of 2 weeks. This situation is distinguished from critical limb ischemia, which is considered a chronic condition, that is, if the symptoms of ischemia last more than 2 weeks. ${ }^{1,2}$

It is a medical emergency that can cause loss of the lower extremities even to death. The patient's output depends on the speed and perfect reperfusion of the affected extremity. ${ }^{1}$ Until now, there has been no definite terminology for how long ischemia affects the outcome. Generally, the considered golden period in the management of ALI is 6 hours. But delays in handling ALI are still common, around $45-66 \%$ of cases. ${ }^{3,4,5,6}$
The incidence of ALI is estimated to be around 140/ 1 million population/ year. The risk of amputation within 30 days is around $10 \%-30 \%$ with a mortality of $15-20 \%$ despite using the latest endovascular techniques and thrombolysis. $^{2}$ At present, there are several methods of revascularization such as thrombolysis (catheter directed thrombolysis), PMT and open surgery. The choice of which revascularization method is the best is still a matter of controversy. ${ }^{2,7}$

\section{Discussion}

Etiology

The main causes of ALI are embolism (30\%) and thrombosis $(60 \%)$. The etiology of ALI as resource of the embolism frequently comes from cardiac chambers because of arrhythmia as atrial fibrillation. Most of the embolism originates from the heart due to valvular disease, prosthetic valves, and mural thrombus in 
myocardial infarction or left ventricular dilatation. Noncardiac sources include arterial aneurysms, atherosclerotic plaque rupture, post-endovascular procedures, and paradoxical embolism from veins or vascular trauma. Whereas acute thrombosis can occur due to in situ thrombosis may cause by plaque rupture or migration of the path towards the distal part. Arterial thrombosis is usually associated with advanced atherosclerosis. ${ }^{8,9,10}$

Arterial embolism has sudden clinical symptoms and is more severe than thrombosis. Embolism will usually clog arteries that were previously healthy, whereas thrombosis usually has formed collateral blood vessels due to chronic ischemia so that clinical manifestations are not as severe as embolism. ${ }^{11,12,13,14}$ Clinically the difference between the two is shown in table 1.

Table 1.

Clinical differences in acute embolism and thrombosis 12

\begin{tabular}{lll}
\hline Clinical symptoms & Embolism & Thrombosis \\
\hline Onset & A few seconds - & A few hours-days \\
Blockage & minutes & There is collateral \\
Multiple locations & Total & Rarely \\
Upper limb involvement & Up to 15\% & Rarely \\
The source of embolism & Frequent (25\%) & There is no \\
History of claudication & There is & There is \\
Palpate the arteries & There is no & Hard \\
Contralateral arterial & Supple & Weak / non- \\
pulsation & Normal & existent \\
\hline
\end{tabular}

\section{Pathophysiology}

Blockage in the arteries will cause tissue perfusion disorders and trigger the formation of thrombus which can then expand. Cells that run into ischemia will have anaerobic metabolism resulting in acidosis and reduced formation of adenosine triphosphate (ATP). The Na-K-ATP pump cannot work so that sodium and water retention in the cell occurs. The calcium pump is also disrupted so that intracellular calcium levels will increase. Increased intracellular calcium activates cytosolic enzymes that can trigger cell damage. Furthermore, the release of toxic substances into the circulation is due to damage to cell membranes. Precapillary arteriole cells also run into swelling so that the distal lumen, capillaries and venules become narrow. Finally, toxic metabolite products will be retained in the network that ischemic. The state of acidosis in cells causes chromatin clumping which eventually leads to cell death. ${ }^{15,16,17,18,19}$

Damage to muscle tissue is the most important aspect in the process of reperfusion injury because muscle is the main constituent tissue of the limb. Skeletal and nerve muscles are the most vulnerable tissues to ischemia. Histological changes occur within 4-8 hours of ischemia in both tissues. ${ }^{19}$

Reperfusion of ischemic extremities can cause a paradoxical reaction known as ischemia-reperfusion injury. This situation is caused by the formation of oxygen free radicals and neutrophil migration due to the return of blood flow to the tissue that ischemic. The local effects of reperfusion are compartment syndrome, necrosis and impaired muscle function. While the systemic impact is known as myonephropathic syndrome which is characterized by acidosis, hyperkalemia which can subsequently cause cardiac arrest, increase in creatine phosphokinase (CPK) and serum glutamic oxaloacetic transaminase (SGOT), myoglobinemia-myoglobinuria which can cause kidney failure, activation of the coagulation cascade, accumulation of SGOT, myoglobinemia-myoglobinuria which can cause kidney failure, activation of the coagulation cascade, accumulation of SGOT, myoglobinemia-myoglobinuria which can cause kidney failure, activation of the coagulation cascade, accumulation of SGOT, myoglobinemia-myoglobinuria which can cause kidney failure, activation of the coagulation cascade, accumulation of SGOT extracellular and acute pulmonary insufficiency. ${ }^{12,13,20}$

\section{Diagnosis}

Acute limb ischemia is a clinical diagnosis. It is clinically recognized by the $6 \mathrm{P}$ mark, namely pain, pallor, pulselessness, paresthesia, paralysis and poikilothermic. The diagnosis of ALI is based on history, physical and supporting examination. ${ }^{4,16}$

History of illness includes complaints related to ischemic conditions in the lower extremities and disease background. Pain and dysfunction are the main complaints of ALI patients. Initially the pain is felt in the distal area of the lower extremity and then extends to the proximal area, but in the advanced stages the pain intensity will decrease with the loss of nerve sensibility. To look for background disease, it is necessary to ask whether there is a history of intermittent claudication, history of interventions due to blood flow disorders, history of heart disease or aneurysm and also risk factors for atherosclerosis such as smoking history, dyslipidemia and diabetes mellitus. ${ }^{2,17}$

Physical examination includes local conditions in the lower extremities and also general conditions related to cardiovascular status and risk of bleeding. At the beginning of ischemia, the skin appears pale due to arterial vasospasm in the distal occlusion area. A few hours later the skin will appear bluish that disappear with pressure, because vasospasm begins to decrease so that the blood vessels are filled with deoxygenated blood. In the later stages the bluish color does not disappear withpressure, because there is coagulation of blood in the branches of the arteries. The palpation of the extremities will feel cold. Muscles that feel hard like wood show muscle infarction with edema and are a sign of irreversible ischemia. Examination of the lower extremities should also be seen for signs of chronic ischemia such as skin atrophy, hair loss and nail thickening. ${ }^{17,21,22}$

Palpation of peripheral arteries varies in accuracy. Palpable arterial pulses are suggestive of ALI but are not diagnostic, whereas palpable pulsations do not exclude 
ALI diagnosis. Therefore, it is necessary to use duplex ultrasound to get objective results. ${ }^{2,23}$

Examination of arterial pulsation in the contralateral lower limb can be used to estimate the etiology of the blockage. Weak pulsation in the contralateral lower limb indicates a background of chronic arterial obstructive disease and means the possibility of thrombosis as a cause of acute ischemia. Whereas arterial pulsation in the contralateral lower extremity is normal, the probable cause of arterial obstruction is embolism.17An arterial pulsation examination can also be used to estimate the location of the blockage. For example, a patient with palpable femoral artery pulsation, while popliteal artery pulsation is not palpable, may be a blockage in the femoral artery segment. If the femoral artery pulsation is not palpated, there is a possibility that the disturbance is above the inguinal ligament. ${ }^{14,23}$

To prove the existence of hypoperfusion in the limbs a Buerger test can also be performed. In normal people the legs can be raised to 90 degrees, and the toes remain red. In limbs that have ischemia removal of 15-30 degrees already causes pale and if the legs are positioned lower limbs will have reactive hyperemia. The angle at which the limb turns pale when the leg is raised is called the Buerger angle..$^{22}$

Neurological examination is intended to assess motor and sensory function. Numbness or paresthesia is an early sign of a nervous breakdown due to ischemia. Severe impairment of sensory and motor functions is a sign of advanced ischemia. ${ }^{17}$

A condition that resembles ALI to think about is Blue toe syndrome. This situation is caused by the presence of atheroembolism in the form of cholesterol microcrystalline debris from arterial plaque that has ruptured in the proximal region. As a result, local ischemia occurs in the toes that are marked bluish, cold and pain that arises suddenly but on palpation still obtained distal arterial pulsation. This situation is a risk that episodes of embolism will occur in the future. ${ }^{14,17}$

Societies of Vascular Surgery/ International Society of Cardiovascular Surgery (SVS/ ISCVS) make the ALI classification into 4 categories based on the severity of the disease, as in table 2.

\section{Differential Diagnosis}

The differential diagnosis needs to be known because there are several conditions that resemble ALI which are contraindicated anticoagulant administration. The differential diagnosis of ALI includes non-vascular musculoskeletal trauma, arterial trauma, radiculopathy (spinal stenosis, vertebral disc herniation), popliteal cysts, phlegmasia cerulean dolens, aortic dissection and compartment syndrome. Systemic disorders such as cardiogenic shock or sepsis can also manifest as ALI. Drugs such as cocaine and vasopressors can also cause severe vasospasm so that the extremities have acute ischemia. $^{2,4,16}$
Table 2.

Classification of the severity of ALI based on SVS / ISCVS2)

\begin{tabular}{|c|c|c|c|c|c|}
\hline \multirow{2}{*}{$\begin{array}{l}\text { Cate- } \\
\text { gory }\end{array}$} & \multirow{2}{*}{$\begin{array}{l}\text { Description } \\
\text { Prognosis }\end{array}$} & \multicolumn{2}{|l|}{ Clinical } & \multicolumn{2}{|c|}{ Doppler signal } \\
\hline & & $\begin{array}{l}\text { Sensory } \\
\text { disorders }\end{array}$ & $\begin{array}{l}\text { Muscle } \\
\text { weakness }\end{array}$ & Artery & Vein \\
\hline $\mathrm{I}$ & $\begin{array}{l}\text { Threatened/not } \\
\text { threatened } \\
\text { immediately }\end{array}$ & $(-)$ & $(-)$ & $(+)$ & $(+)$ \\
\hline \multirow[t]{2}{*}{ II } & $\begin{array}{l}\text { Marginal / can be } \\
\text { saved if treated } \\
\text { immediately }\end{array}$ & $\begin{array}{l}\text { Minimum / ( } \\
\text { ) }\end{array}$ & $(-)$ & Often (-) & $(+)$ \\
\hline & $\begin{array}{l}\text { Immediately/can be } \\
\text { saved if } \\
\text { revascularization } \\
\text { immediately }\end{array}$ & Rest pain & $\begin{array}{l}\text { Mild/ } \\
\text { moderate }\end{array}$ & $\begin{array}{l}\text { Almost } \\
\text { always } \\
(-)\end{array}$ & $(+)$ \\
\hline III & $\begin{array}{l}\text { Irreversible / } \\
\text { extensive tissue } \\
\text { death or permanent } \\
\text { nerve damage }\end{array}$ & $\begin{array}{l}\text { Progressive } \\
\text { /Anesthesia }\end{array}$ & $\begin{array}{l}\text { Progressive } \\
\text { /paralysis }\end{array}$ & $(-)$ & $(-)$ \\
\hline
\end{tabular}

\section{Supporting examination}

Supporting examination that need to be done in ALI patients include routine blood, blood chemistry, coagulation function (prothrombin time, partial thromboplastin time), CPK and electrocardiogram.,24 Arteriography with contrast is still the gold standard for the diagnosis of ALI if there are no contraindications such as kidney disorders or contrast allergy. ${ }^{23}$ Arteriography can distinguish thrombosis from embolism. Embolism appears as filling defect, firm round border with meniscus sign, other blood vessels are normal, no collateral circulation is obtained and multiple filling defects are present. While thrombosis appears as a clear non-circular border and the presence of atherosclerosis and collateral blood vessels. ${ }^{17}$

Alternative imaging examinations other than arteriography are duplex ultrasonography, computed tomographic angiography (CTA) and magnetic resonance angiography (MRA). Duplex ultrasonography (DUS) can be used to determine the location of obstruction, assess plaque morphology, stenosis, dissection and thrombus. The role of DUS for the diagnosis of ALI is very important because DUS is the first imaging choice to assess ALI. It is widely available, has a low cost, is non-invasive, nonirradiant and it takes a relative short time to perform. The sensitivity of this tool is around $80-98 \%$ and the specificity is $89-99 \%$. CTA and MRA are less invasive than conventional arteriography. CTA has a sensitivity of 89$99 \%$ and a sensitivity of $83-97 \%$, while MRA has a sensitivity of $92-99.5 \%$ and a sensitivity of $64-99 \%$. $^{2,14,25}$

Echocardiographic examination in ALI patients is useful for finding the source of embolism from the heart. If transthoracic echocardiography is not found the source of embolism and the suspected cause of ALI is embolism then it should be done transesophageal echocardiography. ${ }^{26,27,28}$ Echocardiography can also see the possibility of paradoxical embolism. ${ }^{29}$ 


\section{Management}

Initial ALI therapy aims to prevent thrombus expansion and worsening ischemia. This can be achieved by administering intravenous unfractionated heparin (UFH) immediately after the diagnosis of ALI is based on clinical appearance. Heparin therapy should not be postponed for reasons of waiting for investigations. After initiation of heparin therapy further therapy depends on limb viability as shown in figure 1. Antiplatelet therapy is also recommended to be given immediately with aspirin 75$325 \mathrm{mg}^{2,14,21}$

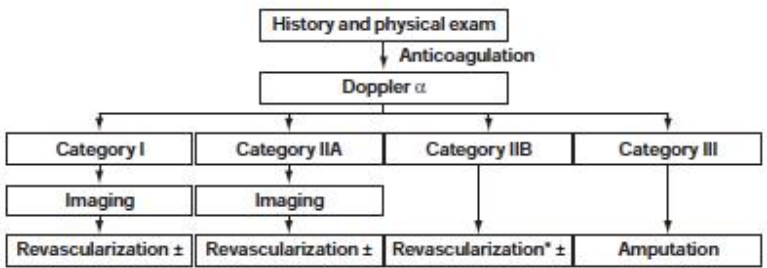

Figure 1. Algorithm for the management of acute limb ischemia. $^{2}$

Category I - Viable; Category IIA - Marginally Threatened; Category IIB - Immediately Threatened; $\alpha$ - Confirming either absent or severely diminished ankle pressure/signals; *In some centers imaging would be performed.

Revascularization in ALI can be done with thrombolysis or surgical therapy. ${ }^{11}$ Percutaneous mechanical thrombectomy (PMT) is another modality that can be used to overcome the limitations of thrombolysis. ${ }^{2,21}$

\section{Thrombolysis}

Definition of thrombolysis in ALI is generally intraarterial thrombolysis with endovascular techniques orCDT (Catheter Direct Thrombolysis). Results confirm the high direct technical success rate of CDT and the high percentage $(88.5 \%)$ of patients survived without amputation within 30 days, although major complications are a greatdisadvantage of the method. ${ }^{43}$ Systemic thrombolytic administration has been abandoned because of the greater risk of bleeding., ${ }^{2,30}$ Several studies report the use of intravenous thrombolysis is quite safe with a successful reperfusion of about $76-77 \%$ without major bleeding complications. ${ }^{31,32}$ But the number of samples in these studies is small.

Thrombolytic drugs work indirectly to destroy fibrin by converting plasminogen to plasmin. ${ }^{33}$ Streptokinase is the first indirect plasminogen activator used for intrarterial thrombolysis, but now its use has been restricted in America because of its lower efficacy and higher bleeding risk compared to other drugs. In addition, streptokinase has the potential to trigger allergic reactions. Urokinase, a direct plasminogen activator is also not used in America because of production reasons. ${ }^{7,24}$

There are currently several thrombolytic drugs such as alteplase a recombinant tissue plasminogen activator (rtPA) derived from human tissue plasminogen activator
(tPA) clones and those derived from tPA genetic engineering such as reteplase (rPA) and tenecteplase (TNK). These drugs have different half-lives, specificity for fibrin (differences in activity against fibrin bound plasminogen compared to circulating plasminogen) and affinity for fibrin (stability of bonds to fibrin). This difference is a consideration for drug selection in the thrombolysis / CDT action. Theoretically rPA can penetrate into the thrombus better than alteplase, an rtPAso that thrombolysis time is faster and consequently the risk of bleeding is smaller. TNK is fibrinolytic which has the highest fibrin specificity. In theory TNK has less effect on plasminogen activation in circulation and thrombolysis time is faster than rPA or rtPA because it is more resistant to plasminogen activator inhibitor-1. But the level of clinical evidence is still weak. ${ }^{24,33}$

Current thrombolytic drugs have several limitations. On average these drugs take about 24 hours to restore blood flow so they are not used in patients with category IIb. Besides, systemic effects (lytic state) due to hypofibrinogenemia can still occur despite using fibrin specific drugs and given locally. Therefore, thrombolytic administration must consider several contraindications such as cerebrovascular attack, active bleeding, intracranial injury and other conditions with a risk of bleeding. ${ }^{14.33}$

Post heparin thrombolysis should be given to prevent retrombosis of blood vessels and prevent thrombosis around the catheter. When given with thrombolytic agent, heparin is given in low doses (subtherapy) because in the presence of fibrinogen degradation products bleeding will be easier. Usually a dose of 200-500 units per hour is used with a PTT target of 1.25-1.5 times the control. ${ }^{14,24,30}$

\section{Percutaneous Mechanical Thrombectomy (PMT)}

PMT is especially useful in patients who have contraindications to thrombolysis and can be used as adjunctive therapy for incomplete thrombolysis. This tool can also reduce the mass of the thrombus (debulking) before thrombolysis so that the reperfusion time is faster. ${ }^{30}$ Some tools used include simple aspiration type catheters, rotational or hydraulic recirculation devices, (Helix, Angiojet, Trellis ${ }^{\circledR}$ ) and ultrasound enhanced thrombolysis (Ekosonic $\left.{ }^{\circledR}\right){ }^{21}$ This method resulted in amputation free survival of $94.7 \%$ with a mortality of $29.6 \%$ in 5 years. $^{34}$

\section{Percutaneous transluminal angioplasty}

Percutaneous transluminal angioplasty (PTA) is useful for repairing arterial obstruction due to atherosclerotic processes. However, the results of infra-inguinal artery blockage are less satisfactory. The risk of perforation and distal embolism is increased when PTA is used on long obstruction. Angioplasty with conventional old plain balloon angioplasty (POBA) has a risk of occurrence dissection, acute elastic recoil, restenosis due to intima hyperplasia and negative remodeling. Several new technologies have been developed to overcome the 
limitations of PTA, including by cutting or scoring balloons and cryoplasty. ${ }^{35}$

Until now, the installation of drug-eluting stents for peripheral arteries has not been approved in America because of the high restenosis rate $(75 \%)$, while the use of nitinol stents has been approved by the Food and Drug Administration (FDA). Nitinol stents are a mixture of nickel and titanium which have super elastic properties (can return to their original form if external pressure is removed) and have a thermal shape memory (return to the previous form on heating). Therefore, this tool can be used for areas that to do flexion or torsion movements such as the superficial femoral artery or the popliteal artery. ${ }^{35}$

\section{Surgical revascularization}

Indications for surgical revascularization are category IIb ischemia. Surgery can be a thromboembolectomy with a balloon catheter (Fogarty) or bypass surgery. Surgical strategy is determined by the etiology of arterial occlusion (embolism or thrombosis) and anatomical features of blood vessels. $^{7}$

The addition of intraoperative thrombolytic drugs can be beneficial because residual thrombus is often obtained after surgical thromboembolectomy (36\%) and thrombus in small blood vessels is often unreachable. ${ }^{36}$ Intraoperative angiography can be used to assess the success of reperfusion. ${ }^{21}$

Until now, there is still controversy over which reperfusion therapy will be chosen, thrombolysis or surgery. Usually category IIa and IIb are used as a limit to determine the type of reperfusion therapy. ${ }^{7,36}$ Some random studies like Rochester study, Thrombolysis or peripheral arterial surgery (TOPAS) and Surgery versus thrombolysis for ischemia of the lower extremity (STILE) showed no difference in mortality and amputation free survival in 30 days on thrombolysis therapy and surgical therapy. ${ }^{37,38,39}$ But these studies have different characteristics of the study population such as the duration and severity of ischemia, the type of thrombolytic used and the length of follow-up. ${ }^{2,17}$

Usually the selection of revascularization therapy is based on the severity of ischemia, etiology, location of the occlusion and the general condition of the patient. Thrombolysis is the treatment of choice for ALI patients with categories I and IIa (class I, Level of Evidence: A), whereas patients with progressive ischemia or category IIb are indicative of surgical revascularization. Thrombolysis therapy can also be considered in category IIb (class IIb, Level of Evidence: B). Infrainguinal or distal arterial thrombolysis has less satisfactory outcomes than ileofemoral or proximal. In cases of embolism, surgical therapy or thrombolysis can be used whereas in cases of thrombosis it requires more complex procedures such as bypass surgery or POBA.,21,40

\section{Prognosis}

The risk of amputation of ALI patients within 30 days is about $10 \%-30 \%$ with a mortality of $15-20 \%$. 2 Some factors that influence outcomes include old age, duration of ischemia, severity of ischemia, etiology of blockage, and accompanying diseases such as diabetes mellitus, history ischemic heart disease and heart failure. ${ }^{3,5,41,42}$

\section{Aknowlegement}

Author declares that there is no conflict of interest in the preparation of the manuscript.

\section{Conclusion}

Acute limb ischemia (ALI) is a vascular emergency with high morbidity and mortality. Early recognition and immediate revascularization are the keys to success management of ALI. Heparinisation therapy must be given immediately when a clinical diagnosis has been established without waiting for the results of investigations.Until now there has been no evidence of differences in the efficacy of thrombolysis with surgical therapy. Consideration of the choice of revascularization therapy is based on the severity of ischemia, etiology, location of occlusion and general condition of the patient.

\section{References}

1. Katzen BT. 2002. Clinical diagnosis and prognosis of acute limb ischemia. Rev Cardiovasc Med, 3:Suppl 2:S2

2. Norgren L, Hiatt WR, Dormandy JA, NehlerMR, Harris KA, Fowkes FG. 2007. Inter-Society consensus for the management of peripheral arterial disease (TASC II). J VascSurg, 45:Suppl S40-60

3. Mutirangura $\mathrm{P}$, Ruangsetakit, Wongwanit C, Sermsathanasawadi N, Chinsakchai K, 2008. Acute arterial embolismsm of the lower extremities: impact of 24-hour duration on the outcome of management. J Med Assoc Thai, 91:1360-1367.

4. Lin M. 2009. Acute limb ischemia: what are the newest diagnostic treatment options? ACEP Scientific Assembly, Boston

5. Earnshaw JJ, Whitman B, Foy C. 2004. national audit of thrombolysis for acute leg ischemia (natali): clinical factors associated with early outcome. J Vasc Surg, 39:1018-1025.

6. Fagundes C, Fuchs, FD, Fagundes A, Poerschke RA, Vacaro MZ. 2005. Prognostic factors for amputation or death in patients submitted to vascular surgery for acute limb ischemia. Vasc Health Risk Manag, $1: 345-349$.

7. Creager MA, Kaufman JA, Conte MS. 2012. Acute limb ischemia. N Engl J Med, 366:2198-2206.

8. Shammas NW. 2006. Dethrombosis of the lower extremities: pharmacologic and mechanical techniques. Vasc Dis Manag, 235-239. 
9. Sobel M, Verhaeghe R. 2008. Antithrombotic therapy for peripheral artery occlusive disease, American College of Chest Physicians evidence based clinical practice guidelines (8th Edition). Chest, 133;815S843S.

10. Mutirangura $\mathrm{P}$, Ruangsetakit C, Wongwanit C, Sermsathanasawadi N, Chinsakchai K, 2009. Clinical differentiation between acute arterial embolismsm and acute arterial thrombosis of the lower extremities. J Med Assoc Thai, 92:891-897.

11. Rutherford RB. 2009. Clinical staging of acute limb ischemia as the basis for choice of revascularization method: when and how to intervene. SeminVasc Surg, 22:5-9

12. Callum K, Bradbury A. 2000. Acute limb ischaemia. BMJ, 320:764-767.

13. Dorweiler B, Pruefer D, Andrasi TB, Maksan SM, Schmiedt W, Neufang A, et al. 2007. Ischemiareperfusion injury pathophysiology and clinical implications. Eur J Trauma Emerg Surg, 33:600-612.

14. Tucker SW, Pamoukian VN, Shortell CK. 2007. Pulseless extermity and atheroembolism. ACS Surgery: Principles and Practice. 1-12

15. Kumar V, Abbas AK, Fausto N, Aster JC. 2010. Cellular responses to stress and toxic insults: Adaptation, Injury and Death. In Robins \&Cotran. Pathologic Basis of Diseases -8th ed. Saunders Elsevier, Philadelphia

16. Kasirajan K, Ouriel K, 2005. Acute limb ischemia. In Rutherford, Vascular surgery [edited by] Robert B. Rutherford. 6th ed. Elsevier Saunders, Philadelphia, Pennsylvania

17. Mitchell ME, Mohler ER, Jeffrey $P$ Carpenter JP, Clement DL, Hoekstra J, et al. 2008. Acute arterial occlusion of the lower extremities (acute limb ischemia). UpToDate v.19.1

18. Padberg F, Duran WN. 2009. Metabolic and systemic consequences of acute limb ischemia. In Comprehensive Vascular and Endovascular Surgery. John WH, Joseph LM, Jonathan E, et al. Elsevier, Philadelphia

19. Blaisdell FW. 2002. The pathophysiology of skeletal muscle ischemia and the reperfusion syndrome: a review. Cardiovasc Surg,10:620-630.

20. Duran WN, Pappas PJ, Boric MP, Hobson RW. 2004. Pathophysiology of skeletal muscle ischemiareprfusion injury. In Enrico A., Henry H. Haimovici's vascular surgery, Volume 151. John Wiley \& Sons

21. Hynes BG, Margey RJ, Ruggiero N, Kiernan TJ, Rosenfield K, Jaff MR. 2012. Endovascular management of acute limb ischemia. Ann Vasc Surg, 26:110-124.

22. Tailor J. 2008. Acute limb ischaemia. Student BMJ,16:80-81
23. Ouriel K, Kashyap VS, 2011. Acute limb ischemia. In Michael R, Christopher JW, (ed). Vascular Disease: Diagnostic and Therapeutic Approaches. Minneapolis: Cardiotext Publishing

24. Morrison HL. 2006. Catheter-directed thrombolysis for acute limb ischemia. Semin Intervent Radiol, 23:258-269.

25. Collins R, Cranny G, Burch J, Aguiar-Ibáñez R, Craig D, Wright $\mathrm{K}$, et al. 2007. A systematic review of duplex ultrasound, magnetic resonance angiography and computed tomography angiography for the diagnosis and assessment of symptomatic, lower limb peripheral arterial disease. Health Technol Assess, 11:20.

26. Blebea J, Kempczinski RF. 1995. Acute limb ischemia In Richard HD, James ST, David CB. Current Diagnosis \& Treatment in Vascular Surgery. Appleton \& Lange. East Norwalk Connecticut

27. Tofigh AM, Karvandi M, Coscas R. 2008. Current incidence of peripheral arterial embolismsm and role of echocardiography. Asian CardiovascThorac Ann, 16:439-443.

28. Sal R, Cormier JM, Chapoutot L, AlaméA, Al-Khedr A, Raynaud JC, et al. 1996. Acute upper limb ischemia in a young adult without cardiac disease. Value of transesophageal echocardiography. Arch Mal Coeur Vaiss, 89:1317-1321.

29. Hajsadeghi S, Kerman SRJ, Farsi N, Rahbar H. 2011. Limb ischemia and dyspnea; a plausible indication of paradoxical embolismsm. Iran Cardiovasc Res J, 5:73-76.

30. Rajan DK, Patel NH, Valji K, Cardella JF, Bakal C, Brown D, et al. 2005. Quality improvement guidelines for percutaneous management of acute limb ischemia. J Vasc Interv Radiol, 16: 585-595.

31. Shrivastava CP, Devgarha S. 2007. Urokinase thrombolysis in acute-on-chronic vascular occlusion of lower limb. Asian Cardiovasc Thorac Ann, 15:405407.

32. Flis V, Kobilica N, Bergauer A, Mrdza B, Milotic F, Stirn B. 2011. Intravenous thrombolysis with recombinant tissue plasminogen activator (rt-pa) in acute lower limb ischaemia. J Inter Med Res, 39:1107-1112.

33. Lyden SP. 2010. Endovascular treatment of acute limb ischemia: review of current plasminogen activators and mechanical thrombectomy devices. Perspect Vasc Surg Endovasc Ther, 22:219-222.

34. Ansel GM, Botti CF, Silver MJ. 2008. Treatment of acute limb ischemia with a percutaneous mechanical thrombectomy-based endovascular approach: 5-year limb salvage and survival results from a single center series. Catheter Cardiovasc Interv, 72:325-330. 
35. Rogers JH, Laird JR. 2007. Overview of new technologies for lower extremity revascularization. Circulation, 116:2072-2085.

36. Bosiers M, Kleinsorge G, Deloose K, Verbist J, Peeters P. 2010. Controversy on acute limb ischemia. Is thrombolysis useful and possible in vascular surgery departments? Surgeon don't be afraid of thrombolysis! it is more efficient and easy to manage in a surgical environment. IMP, 15:102-106.

37. Ouriel K, Shortell CK, DeWeese JA, Green RM, Francis CW, Azodo MV, et al. 1994. A comparison of thrombolytic therapy with operative revascularization in the initial treatment of acute peripheral arterial ischemia. J Vasc Surg, 19:10211030.

38. Ouriel K, Veith FJ, Sasahara AA. 1996. Thrombolysis or peripheral arterial surgery: phase I results. TOPAS Investigators. J Vasc Surg, 23:64.

39. Weaver FA, Comerota AJ, Youngblood M, Froehlich J, Hosking JD, Papanicolaou G. 1996. Surgical revascularization versus thrombolysis for nonembolismc lower extremity native artery occlusions: results of a prospective randomized trial. The STILE Investigators. Surgery versus Thrombolysis for Ischemia of the Lower Extremity. J Vasc Surg, 24:513-523.

40. Hirsch AT, Haskal ZJ, Hertzer NR, Bakal CW, Creager MA, Halperin JL, et al. 2006. ACC/AHA 2005 Guidelines for the management of patients with peripheral arterial disease (lower extremity, renal, mesenteric, and abdominal aortic): Executive Summary A Collaborative Report From the American Association for Vascular Surgery/Society for Vascular Surgery, Society for Cardiovascular Angiography and Interventions, Society for Vascular Medicine and Biology, Society of Interventional Radiology, and the ACC/AHA Task Force on PracticeGuidelines (Writing Committee to Develop Guidelines for the Management of Patients With Peripheral Arterial Disease). J Am Coll Cardiol, 47:1239-1312.

41. Ljungman C, Adami HO, Bergqvist D, Sparen P, Bergström R. 1991. Risk factors for early lower limb loss after embolectomy for acute arterial occlusion: A population-based case-control study. Brit J Surg, 78:1482-1485.

42. Morris-Stiff G, D'Souza J, Raman S, Vannan PS, Lewis MH. 2009. Update experience of surgery for acute limb ischaemia in a district general hospital - are we getting any better? Ann R Coll Surg Engl, 91:637-640.

43. Theodoridis PG, Davos $\mathrm{CH}$, Dodos $\mathrm{I}$, Iatrou $\mathrm{N}$, Potouridis A, Pappas GM, et al. 2018. Thrombolysis in acute lower limb ischemia: review of the current literature. Ann Vasc Surg, 52:255-262. 